\title{
Effect of Inorganic Coagulants on the Characteristics in Anaerobic Digested Distillery Stillage Valorization ${ }^{\dagger}$
}

\author{
Magda Dudek *, Paulina Rusanowska, Marcin Zieliński and Marcin Dębowski \\ Department of Environment Engineering, University of Warmia and Mazury in Olsztyn, \\ Warszawska St. 117a, 10-720 Olsztyn, Poland; paulina.jaranowska@uwm.edu.pl (P.R.); \\ marcin.zielinski@uwm.edu.pl (M.Z.); marcin.debowski@uwm.edu.pl (M.D.) \\ * Correspondence: magda.dudek@uwm.edu.pl; Tel.: +48-89-524-56-08 \\ + Presented at Environment, Green Technology and Engineering International Conference (EGTEIC 2018), \\ Caceres, Spain, 18-20 June 2018.
}

Published: 17 October 2018

\begin{abstract}
The aim of the study was to determine the possibility of using coagulation for treatment of anaerobically digested distillery stillage. Post-fermentation sludge from waste product of bioethanol production is usually drained. Then, condensed sediments are directed as a fertilizer for arable fields. The remaining liquid phase due to the high content of organic compounds cannot be discharged to environment. The study used inorganic salts of iron and aluminum as coagulants to treatment liquid fraction obtained after methane fermentation of distillery stillage. In valorization process, the reduction of organic compounds and suspended solids was not sufficient. The highest doses of coagulants reduced COD concentration of about $80 \%$ and lower the $\mathrm{pH}$ of the solution. However, the dose $10 \mathrm{~mL} / \mathrm{L}$ is not economically profitable and due to concentration of aluminum or iron it is too harmful for environment.
\end{abstract}

Keywords: coagulation; anaerobic leachate; distillery stillage

\section{Introduction}

Depleting fossil fuel resources have increased interest in renewable sources of energy. The most popular among biofuels is bioethanol. In 2015, the bioethanol global production reached the level of 98 billion liters. Distillery stillage is the main waste product of bioethanol production. Inappropriate disposal of the stillage leads to pollution of soil, surface- and ground-waters. The bioethanol production sector faces noticeable challenges, as awareness regarding the environmental impacts caused by the uncontrolled disposal of stillage grows.

Approximately $13 \mathrm{~L}$ of stillage per every $\mathrm{L}$ of bioethanol is produced in the bioethanol process. [1]. Distillery stillage is characterized by complex composition, high BOD5 values and low $\mathrm{pH}$ value, its disposal is a serious environmental problem [2]. Depending on the raw material used to produce bioethanol, concentration of COD of stillage ranges from $10 \mathrm{~g} \mathrm{O}_{2} / \mathrm{L}[3,4]$ to more than $100 \mathrm{~g} \mathrm{O}_{2} / \mathrm{L}$ [5]. They also contain substances such as potassium, phosphates, nitrogen, calcium and sulphates $[6,7]$. The stillage has relatively low sugar content, mainly glucose, but on the other hand, it contains residues of degraded yeast cells, so it could be considered a good nitrogen source [8].

Since stillage contains many valuable ingredients, it is used as fodder, as a base for further microbiological production (for example biogas), as a fertilizer, etc. [9]. The stillage can be processed as a whole or it is screened or centrifuged to produce thin stillage and wet distillers' grain. Separation of wastewaters to tin and concentrated fractions gives new possibilities of their uses [10].

Coagulation and flocculation are the essential processes used for the removal of particulates and organic matter from wastewaters, and are usually conducted by adding chemicals such as salts of aluminum and iron and polyelectrolytes. Coagulation is a chemical process that involves 
neutralization of charge whereas flocculation is a physical process and does not involve neutralization of charge. Coagulation itself results in the formation of floc but flocculation is required to help the floc further aggregate and settle.

The proposed solution for management of post-fermentation effluent from fermentation tank with distillery stillage is to use coagulation. Post-fermentation sludge from biogas plants is usually drained. Then, condensed sediments are directed as a fertilizer for arable fields. The remaining liquid phase due to the high content of organic compounds cannot be discharged to environment. The study used inorganic salts of iron and aluminum as coagulants to treatment liquid fraction obtained after methane fermentation of distillery stillage.

\section{Material and Methods}

The study involved the use of liquid leachate from drainage of post-fermentation sludge. The characteristic of anaerobic digested distillery stillage is presented in Table 1. Four kinds of coagulants with commercial names of PIX 111-iron (III) chloride solution ((Fe) $13.4 \pm 0.6 \%$, $\left(\mathrm{Fe}^{2+}\right)$ max 0.3\%), PIX 123-iron (III) sulfate solution ((Fe) $\left.12.6 \pm 0.3 \%,\left(\mathrm{Fe}^{2+}\right) \max 0.7 \%\right)$, PAX 16-aluminum polychloride solution $\left(\mathrm{Al}_{2} \mathrm{O}_{3} \quad 16 \%\right)$ and $\mathrm{PAX}$ XL $19 \mathrm{H}$-aluminium polychloride solution $\left(\mathrm{Al}_{2} \mathrm{O}_{3} 23.6 \%\right)$ were used. The coagulant dosage ranged from 25 to $400 \mu \mathrm{L} / \mathrm{L}$. Anaerobic digested distillery stillage samples were stirred with coagulants at $400 \mathrm{rpm}$ for $1 \mathrm{~min}$, then the mixing speed was reduced to $80 \mathrm{rpm}$ for $5 \mathrm{~min}$ for flocculation. The sedimentation phase lasted 30 $\min$.

Table 1. Characteristic of anaerobically digested distillery stillage.

\begin{tabular}{ccc}
\hline Indicator & Unit & Value \\
\hline $\mathrm{pH}$ & & 7.8 \\
$\mathrm{COD}$ & $\mathrm{mg} \mathrm{O}_{2} / \mathrm{L}$ & $8365 \pm 23$ \\
Total nitrogen & $\mathrm{mg} \mathrm{N}_{\text {tot }} / \mathrm{L}$ & $1688 \pm 88$ \\
Total phosporus & $\mathrm{mg} \mathrm{P}-\mathrm{PO} / \mathrm{L}$ & $192 \pm 13$ \\
Total solids & $\mathrm{mg} / \mathrm{L}$ & $7115 \pm 102$ \\
\hline
\end{tabular}

COD concentrations were measured with cuvette testes (Hach Lange USA, Loveland, CO, USA) and spectrophotometer UV/VIS (DR 5000). The $\mathrm{pH}$ was measured with multiparameter (Hach Lange HQ 440D).

\section{Results and Discussion}

Usually higher COD removal was achieved with aluminum-contained coagulants. However, the highest COD reduction was achieved with the use of the coagulant PIX 111 in a dose of $300 \mu \mathrm{L} / \mathrm{L}$ (Figure 1). The COD concentration in valorized solution reached $5527 \pm 106.82 \mathrm{mg} \mathrm{O} / \mathrm{L}$. As valorization process ensured only $34 \%$ reduction in COD, in the subsequent studies higher coagulant doses were used, ranged from $0.8 \mathrm{~mL} / \mathrm{L}$ to $10 \mathrm{~mL} / \mathrm{L}$ of digestate.

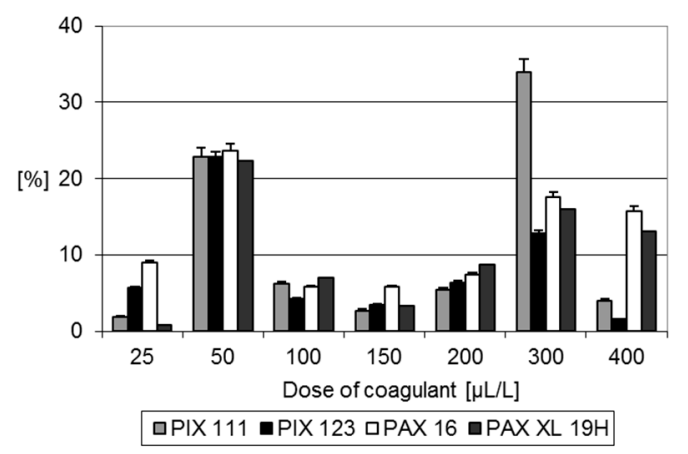

Figure 1. Efficiency of COD removal by coagulation with PIX 111, PIX 123, PAX 16, PAX 19H in the dose ranged from $25-400 \mu \mathrm{L} / \mathrm{L}$. 
Using PIX 111 with a dose of $10 \mathrm{~mL} / \mathrm{L}$, COD concentration in coagulated liquid fraction of digestate of $1480 \pm 132.14 \mathrm{mg} \mathrm{O} / \mathrm{L}$ was achieved. In turn, the same dose of PIX 123 and PAX 16 ensured COD reduction to the level of $2000 \mathrm{mg} \mathrm{O} / \mathrm{L}$ (Figure 2.). The lowest COD removal was noted during the coagulation with PAX XL 19H. Despite high efficiency of COD removal with a dose of coagulat of $10 \mathrm{~mL} / \mathrm{L}$, the process is economically unprofitable. This dose of coagulant also introduce high amount of aluminum/iron in the obtained sludge.

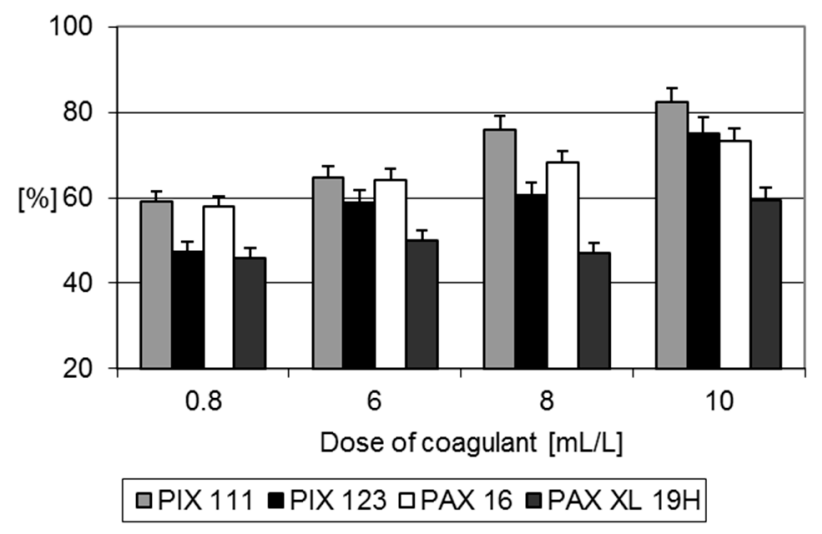

Figure 2. Efficiency of COD removal by coagulation with PIX 111, PIX 123, PAX 16, PAX 19H in the dose ranged from 0.8 to $10 \mathrm{~mL} / \mathrm{L}$.

The coagulation of liquid fraction from methane fermentation of distillery stillage influenced on the $\mathrm{pH}$ values in the obtained solution. The use of high doses of inorganic coagulants resulted in a significant decrease in $\mathrm{pH}$ of the valorized digestate (Figure 3).

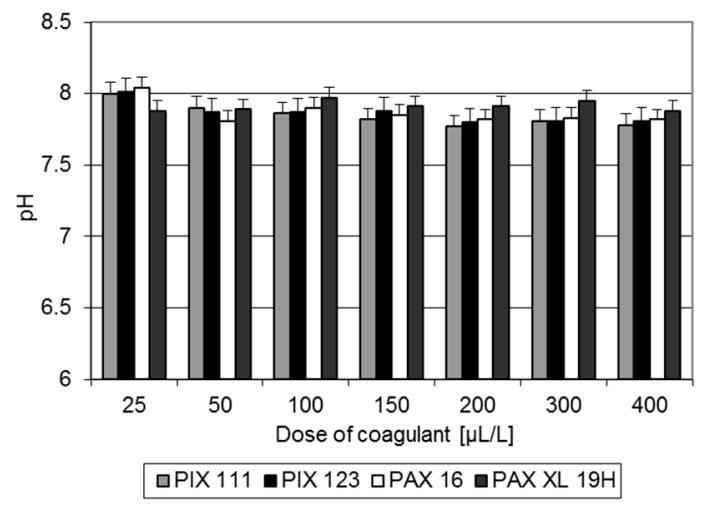

Figure 3. pH during coagulation in the doses of coagulants from 25 to $400 \mu \mathrm{L} / \mathrm{L}$.

The use of the coagulation process appears to be ineffective for treatment of liquid fraction from methane fermentation of distillery stillage. Organic matter removal was low, even at high dosages of coagulants it was not sufficient. Moreover, coagulation generated large amounts of solids difficult to remove via gravity sedimentation. The color of the anaerobic digested distillery stillage was removed slightly.

Author Contributions: M.Z. and M.D. conceived and designed the experiments; M.D. and P.R. performed the experiments; M.D. and M.Z. analyzed the data; M.D. and P.R. contributed reagents/materials/analysis tools; M.D. wrote the paper.

Acknowledgments: The study was carried out in the framework of the project under a program BIOSTRATEG funded by the National Centre for Research and Development "Processing of waste biomass in the associated biological and chemical processes “BIOSTRATEG2/296369/5/NCBR/2016. 
Conflicts of Interest: The authors declare no conflict of interest. The founding sponsors had no role in the design of the study; in the collection, analyses, or interpretation of data; in the writing of the manuscript, and in the decision to publish the results.

\section{References}

1. Kim, J.S.; Kim, B.G.; Lee, C.H.; Kim, S.W.; Jee, H.S.; Koh, J.H.; Fane, A.G. Development of clean technology in alcohol fermentation industry. J. Clean. Prod. 1997, 5, 263-267.

2. Mojovi'c, L.; Pejin, D.; Rakin, M.; Pejin, J.; Nikoli'c, S.; Djuki'c-Vukovi'c, A. How to improve the economy of bioethanol production in Serbia. Renew. Sustain. Energy Rev. 2012, 16, 6040-6047.

3. España-Gamboa, E.; Mijangos-Cortes, J.; Barahona-Perez, L.; Dominguez-Maldonado, J.; Hernandez-Zarate, G.; Alzate-Gaviria, L. Vinasses: Characterization and treatments. Waste Manag. Res. 2011, 29, 1-16.

4. Kharayat, Y. Distillery wastewater: Bioremediation approaches. J. Integr. Environ. Sci. 2012, 9, 69-91.

5. Robles-González, V.; Galíndez-Mayer, J.; Rinderknecht-Seijas, N.; Poggi-Varaldo, H.M. Treatment of mezcal vinasses: A review. J. Biotechnol. 2012, 157, 524-546.

6. Mutton, M.A.; Rossetto, R.; Mutton, M.J.R. Agricultural Use of Stillage. In Sugarcane Bioethanol-RED for Productivity and Sustainability; Cortez, L.A.B., Ed.; Edgard Blücher: São Paulo, Brazil, 2014; pp. 423-440.

7. Wilkie, A.C.; Riedesel, K.J.; Owens, J.M. Stillage Characterization and Anaerobic Treatment of Ethanol Stillage from Conventional and Cellulosic Feedstocks. Biomass Bioenergy 2000, 19, 63-102.

8. Kosseva, M. Sources, characterization and composition of food industry wastes. In Food Industry Wastes: Assessment and Recuperation of Commodities; Kosseva, M., Webb, C., Eds.; Academic Press: London, UK, 2013, pp. 44-48.

9. Qian, P.; Schoenau, J.; Urton, R. Effect of Soil Amendment with Thin Stillage and Glycerol on Plant Growth and Soil Properties. J. Plant Nutr. 2011, 34, 2206-2221.

10. de Sena, R.F.; Claudino, A.; Moretti, K.; Bonfanti, I.C.P.; Moreira, R.F.P.M.; José, HJ Biofuel Application of Biomass Obtained from a Meat Industry Wastewater Plant through the Flotation Process-A Case Study. Resour. Conserv. Recycl. 2008, 52, 557-569.

(C) 2018 by the authors. Licensee MDPI, Basel, Switzerland. This article is an open access article distributed under the terms and conditions of the Creative Commons Attribution (CC BY) license (http://creativecommons.org/licenses/by/4.0/). 